\title{
В.А. Доманский
}

\section{ПОЛИКУЛЬТУРНЫЙ ТЕАТРАЛЬНЫЙ ДИСКУРС ТОМСКА НА РУБЕЖЕ ХIX-XX ВВ. (НА МАТЕРИАЛЕ ГАСТРОЛЕЙ УКРАИНСКИХ ТРУПП)}

\begin{abstract}
В статье рассматривается поликультурный театральный дискурс на материале гастролей украинских трупп. Он велся на страницах томской периодики на рубеже $X I X-X X$ вв. и прежде всего в газете "Сибирский вестник». Представляется возможным сделать вывод, что историю Томского театра преимущественно составляют отдельные сюжеты антреприз и театральных гастролей. Убедительным примером являются гастроли украинской труппь под руководством Ф.А. Хмары, проходившие в Томске в зимний сезон 1903 г. Обзоры спектаклей украинской труппы представлены в рецензиях Вс. Долгорукова, И. Ольгина. Театральными рецензентами проанализирован практически весь репертуар украинской труппы, профессионально оценена игра актеров.

Ключевые слова: томская периодика, театральный дискурс, украинские труппы, театральные критики.
\end{abstract}

развитием сибирской журналистики и открытием в 1888 г. Сибирского императорского университета в Томске стремительно растет и меняется самосознание сибиряков: на страницах газет и печатных изданий происходит встреча разных людей, стран, эпох и культур. История становления и развития сибирской журналистики является своеобразным зеркалом формирования самосознания сибиряков. На материале сибирских газет, журналов, альманахов и сборников можно проследить разные фазы развития «сибирского общества»: от осознания сибиряками своей вторичности и стремления подражать общественным и культурным явлениям Москвы и Петербурга (в конце XVIII - начале XIX в.) до самоидентификации сибиряков в 1860-1880-е гг., а затем до оценки со своих, сибирских позиций, российского Центра, Европы и всего мира.

Анализ сибирской периодики позволяет сделать вывод, что уже в 1880-е гг. появляющаяся сибирская интеллигенция задала такую высокую планку региональной журналистике, какой не было во многих столичных изданиях. Но среди образованных читателей успех имели только те издания, в которых внятно звучали идеи служения Сибири и России. Защищая интересы сибирского общества, журналистика не боялась конфронтации с властями, даже если это 
грозило закрытием печатного органа. Вместе с тем почти каждая сибирская газета имела свои приоритеты, свои неповторимые рубрики, свое лицо.

Особую роль в общекультурном и гражданском становлении сибирской интеллигенции, благодаря своей доступности и силе воздействия на чувства зрителя, играет театр. В Сибири возникают свои театральные труппы и часто гастролируют труппы из российских центров, Украины и даже приезжают артисты из Европы. Практически все ведущие сибирские газеты на своих страницах помещают подробные разборы театральных постановок, игры актеров, а чуть позже даже произведений оперного искусства. Так, в газете «Сибирская мысль», издаваемой в 1906-1918 гг., регулярно начинает выходить рубрика «Театр и искусство», в которой достаточно часто помещаются обзоры оперных спектаклей приезжих трупп: «Евгения Онегина» П.И. Чайковского, «Риголетто» Д. Верди, «Севильского цирюльника» Д.А. Россини, «Лакме» Л. Делиба.

Высокий интерес томской периодики к театру объяснялся тем, что ведущие томские журналисты - Ф. Волховский, Вс. Долгоруков, И. Миллер (И. Ольгин), Г. Вяткин - считали, что театр, благодаря своей доступности и силе воздействия на чувства зрителя, может иметь даже большее значение в деле просвещения, чем книги. В частности, Ф. Волховский, отводя театру огромную роль в «воспитании в обществе всех добрых чувств и стремлений, начиная гуманностью и чувством человеческого достоинства и оканчивая самоотвержением "правды ради"» [1. № 43. С. 1081], выдвигает особые требования к театральному критику и обозревателю. Он должен объяснять зрителю «общественный смысл тех отношений, характеров и обстоятельств, которые составляют содержание пьесы», и воспитывать «правильные эстетические взгляды и инстинкты по отношению к литературе и драматическому искусству» [1. № 48. С. 1225]. Именно эти качества критик демонстрирует при анализе спектаклей томской труппы по пьесам А.С. Грибоедова «Горе от ума», Н.В. Гоголя «Женитьба», «Ревизор».

Воспитанию томских зрителей во многом способствовал репертуap театра, в котором преобладали шедевры русской и мировой театральной классики. Это пьесы Грибоедова и Гоголя, многие драмы Островского, «Разбойники», «Коварство и любовь», «Мария Стюарт» Шиллера, «Фауст» Гете, комедии и трагедии Шекспира, Мольера, 
Бомарше, Гюго, Гуцкова, Зудермана, Гауптмана, Метерлинка и других немецких, австрийских, английских и французских авторов.

В истории культурной жизни дореволюционного Томска одним из самых ярких событий являются гастроли различных театральных трупп - из Центральной России, Москвы и даже Украины, которые охотно отправлялись в университетский Томск, где долгие годы не было своей постоянной труппы, но были культурные и благодарные зрители. Особую главу в театральной жизни Томска составляли гастроли украинских трупп, богатые сведения о которых представлены на страницах «Сибирского вестника». Здесь помещалась информация о труппах, их репертуаре, актерах, публиковались вполне профессиональные рецензии на спектакли.

Надо заметить, что украинские пьесы на томской сцене появились лишь с 1885 г. Это связано с тем, что до 1882 г. из-за репрессивного Валуевского указа украинского профессионального театра не существовало. И лишь 10 января 1882 г. в Киеве появилась украинская труппа, созданная М.Л. Кропивницким при участии выдающихся украинских актеров Н.К. Садовского и М.К. Заньковецкой. Начался невиданный подъем украинского театра. Появился замечательный украинский репертуар, в который вошли произведения украинских классиков, а также создателя театра М.Л. Кропивницкого. Они отличались знанием народной жизни, сценичностью и хорошим украинским языком. Мода на украинский театр распространилась далеко за пределы Украины. Дошла она и до Сибири и Дальнего Востока, куда в это время переселялись тысячи украинцев.

В Томске сначала ставились украинские любительские спектакли, о чем информирует нас «Сибирский вестник» за 1885-1887 гг. С 1888 г. на городских сценах начали гастролировать театральные труппы, сначала из Дальнего Востока, а затем из крупных украинских городов. Так, в 1890 г. с небольшими гастролями в Томске выступала труппа Деркача, которая привезла несколько украинских пьес, получивших пока довольно сдержанный отзыв Неизменного театрала, т.е. Всеволода Алексеевича Долгорукова, подписывающего свои рецензии этим псевдонимом.

В 1891 г. на томской сцене с большим успехом и денежными сборами идут несколько украинских пьес и водевилей. Это прежде всего драма Т.Г. Шевченко «Назар Стодля» и водевиль В. Дмитриенко «Кум-мирошник, или Сатана в бочке». 
В 1893 и 1894 гг. украинские труппы в Томске не гастролировали, и театральная публика их заждалась. Поэтому неслучайно на летних гастролях украинской труппы в 1894 г. в Томском театре был аншлаг. Еще до приезда в «Сибирском вестнике» № 74 от 26 июня и № 77 от 29 июня появляется информация о скором прибытии театральной труппы из Украины.

Затем буквально в каждом номере этого же издания на протяжении месяца в рубрике «Театр и музыка» публикуются рецензии Лешина (видимо, один из псевдонимов Вс. Долгорукова), посвященные спектаклям украинской труппы («Назар Стодоля» Т. Шевченко, «Сватання на Гончарівці» Г. Квитки-Основьяненко, «НаталкаПолтавка» И. Котляревского). В «Сибирском вестнике» № 90 за 5 августа публикуется обзорная рецензия Лешина о гастролях труппы.

Новые гастроли украинских трупп возобновились в июле 1896 г. и прошли в театре Е.И. Королева. В томской печати они отражены бегло. Зато гастроли украинской труппы К.П. Мирославского, талантливого актера, режиссера, антрепренера и драматурга, в феврале 1897 г. были отмечены многими серьезными рецензиями-разборами Всеволода Долгорукова, который на этот раз печатался под псевдонимом $B$. До-ков. Гастроли труппы Мирославского были омрачены скандалом, разгоревшимся из-за содержания некоторых пьес, входивших в репертуар труппы.

Следующий, 1898 г., оказался весьма урожайным для томской сцены на украинские спектакли. В начале сентября прибывает из Киева труппа М.Л. Кропивницкого, уже получившая к этому времени признание не только на Украине, но и в российских столицах. Ее спектакли были восторженно приняты томской публикой, хотя мелодрама И. Потустороннего «Жидовка-выкрестка» вызвала неоднозначную реакцию зрителей и рецензентов [2. 1898. № 197. 12 сент.].

В конце сентября в Томск прибывает труппа тоже известного актера, режиссера и антрепренера П.П. Струйского, который с успехом ставит драмы на русском языке, а комедии, водевили и мелодрамы на украинском. Всеволод Долгорукий (Всев. Долг-ков) на страницах «Сибирского вестника» публикует несколько театральных рецензий, в которых сравнивает уровень постановок пьес русского и украинского репертуара, отдавая предпочтение исполнению актерами пьес украинских. 
В 1899, 1890, 1902 гг. в Томске гостило несколько украинских трупп: Василенко и Сабинина, Каганца, Морозенко. На страницах «Сибирского вестника» публикуется ряд рецензий разных авторов на спектакли украинских трупп. Среди них своим глубоким аналитическим разбором игры актеров и постановок в целом отличаются рецензии Вс. Долгорукова (Старый литератор, Вова). Рецензии Б. Песчанца и Ми (Михайлов Константин Арсеньевич?) носят более популяризаторский характер.

Как видим, историю Томского театра преимущественно составляют отдельные сюжеты из истории антреприз и театральных гастролей. Они, к сожалению, до сих пор практически не описаны, хотя томская периодика предоставляет обильный материал для изучения этой темы. Один такой интересный сюжет представляют собой гастроли украинской труппы Ф.А. Хмары. Эти гастроли проходили в Томске в период с начала января до середины февраля 1903 г. в обычные дни в здании бесплатной народной библиотеки, а по праздникам - в помещении Общественного собрания. Репертуар труппы Хмары состоял преимущественно из украинских оперетт и инсценировок по произведениям украинских писателей, а также некоторых оперетт русских авторов. Томская публика очень хорошо приняла представления украинской труппы, о чем уже свидетельствует рецензия И. Ольгина (И.Л. Миллер) в «Сибирском вестнике» от 5 января под названием «Первая гастроль малороссов»: «Бесплатная библиотека уже давно не вмещала столько публики в себе, сколько было на первом спектакле 3 января, прибывшей к нам малороссийской труппы Ф.А. Хмара. Билеты задолго до начала спектакля были распроданы, очень много публики толпилось в дверях и проходах, а многим приходилось возвращаться домой, не попав на спектакль. Поставленная драматическая оперетка Старицкого «Цыганка Аза» ${ }^{1}$, шедшая уже неоднократно у нас, была исполнена с полным ансамб-

${ }^{1}$ Романтическая драма Михаила Старицкого «Цыганка Аза» (1888) сюжетно восходит к повести Ю. Крашевского «Хата за селом», хотя намного превосходит свои первообразы по своей динамике, разработке характеров и языковой выразительности. Ее сюжет - трагическая и поэтичная история обреченной любви, о попытке вырваться из жестких рамок традиций. Драма привлекает динамичным и увлекательным сюжетом, живописностью сцен, неповторимым народно-песенным колоритом, утверждением общечеловеческих нравственноэтических норм. 
лем и оставила по себе самое лучшее впечатление» [2. 1903. № 4. 5 янв. С. 3].

Автор рецензии сравнивает первое впечатление от игры труппы Хмары и приходит к выводу, что она значительно превосходит труппы Морозенко и Каганца, гастролировавшие ранее в Томске. Он отмечает достойный профессиональный уровень хора и оркестра, а также новизну и свежесть костюмов. Но главное - это хорошее исполнение вокальных номеров артистами Ясновской, Антонович и Черновым и залихватская пляска, которая, по его словам, вызвала восторг у публики. Рецензент в особенности выделяет игру артистки Антонович (Галя) в роли Азы, а также исполнителей ролей Лопуха (Зозуля), Васыля (Чернов) и Панаса (Хмара).

«Сибирский вестник» постоянно из номера в номер помещает на первой странице анонсы об опереттах украинской труппы, из которых можно узнать, что почти вся украинская опереточная классика была поставлена на этих гастролях в Томске.

Интересно, что в это же время на сцене театра Королёва шли драматические спектакли русской труппы Ю.Ф. Строговой, которые имели значительно меньший успех, о чем свидетельствуют рецензии того же И. Ольгина и Всеволода Долгорукова, подписывающего свои рецензии псевдонимом Неизменный театрал. Так, например, ничего лестного не было высказано рецензентом о спектакле по комедии Н.А. Борисова «Бирон» ${ }^{1}$, а спектакль по драме А. Суворина «Татьяна Репина» ${ }^{2}$ назван безжизненным и бледным, за исключением игры «г-жи Строговой в роли Кокошкиной» [2. 1903. № 9.12 янв. С. 3]. И. Ольгин не смог дать положительной оценки и спектаклю русской труппы по комедии А.П. Чехова «Три сестры» [2. 1903. № 8. 11 янв. С. 2].

Украинская труппа ставила также и оперы, и первой на томской сцене была поставлена опера украинского композитора С. Гулака-

${ }^{1}$ Борисов Николай Александрович (1850-1900) - драматург, автор нескольких водевилей. Особенным успехом пользовались его пьесы «Бирон» и «Следователь».

${ }^{2}$ Суворин Алексей Сергеевич (1834-1900) - русский журналист, издатель, писатель, театральный критик, драматург, автор пользовавшейся большим успехом драмы из жизни актёров «Татьяна Репина» (1899), которая навеяна реальным событием - самоубийством в 1881 г. в Харькове молодой актрисы Евладии Кадминой. 
Артемовского «Запорожец за Дунаем». В своей рецензии, помещенной в рубрике «Театр и музыка» под названием «Спектакль малороссов в общественном собрании», Всеволод Долгоруков отмечал, что «труппа Хмары будет иметь успех, так как в Томске немало любителей малороссийских мотивов». И уже первое исполнение ею оперы произвело «впечатление благоприятное». Опытный театральный критик неплохо разбирался в специфике оперного искусства и профессионально оценивал пение актеров: «Госпожа Ясновская обладает хорошим голосом приятного тембра и имела успех в роли Одарки, жены запорожца Ивана Карася; недурной голос и у г-жи Антонович, выступавшей в роли Оксаны, приемной дочери Карася. Правда, - отмечал при этом рецензент, - голос этот необработан, слаб на нижнем регистре, но исполнение простых малороссийских мотивов ей удается, и впечатление получается хорошее. Недурной баритон и у Чернова, исполнявшего роль молодого казака Андрия». Несомненным достоинством игры двух ведущих актрис, Ясновской и Антонович, Долгоруков считал также их «довольно прочувствованную игру» [2. 1903. № 6.9 янв. С. 3].

Еще одной удачной постановкой украинской труппы, по мнению рецензента И. Ольгина, была оперетта по пьесе А.Л. Суходольского «Майская ночь» (по мотивам произведения Н.В. Гоголя). «Особенно удачным, - по его мнению, - нужно считать первый акт, где артисты имели положительно выдающийся успех. Хоры звучали очень стройно, а игра г-ж Ясновской и Антонович подкупала зрителей своей непринужденностью» [2. 1903. № 7. 10 янв. С. 3].

И. Ольгин отмечает неизменный успех украинской труппы: «В общем спектакль прошел хорошо, и все участвующие удостоились аплодисментов и вызовов, а музыкальные номера были бисированы» [Там же].

Особого успеха у томской публики, как пишет в следующей своей рецензии И. Ольгин, был удостоен спектакль по драме И.П. Котляревского «Наталка-Полтавка». В «Наталке-Полтавке» ему понравилась непринужденная игра С.М. Антонович, выступавшей в заглавной роли. Он сообщает, что «вокальные номера, выполненные г-жой Антонович, слушались с большим удовольствием». С неподдельным комизмом исполняли свои роли артисты Хмара (возный) и Зозуля (выборный). В заключение спектакля были поставлены «цыганские песни в лицах», в которых в роли Стеши появилась артистка 
Ясновская и своей игрой и пением заслужила громкие аплодисменты.

Совсем другое впечатление произвела на зрителей оперетта И. Захаренко (1839-1908) «Червоні черевики». Она не вызвала особого интереса, так как в ней, полагает автор рецензии, много скучных разговоров и акты слишком растянуты. «Это чуть ли не самая неудачная пьеса из репертуара малороссийских опереток, - заключает И. Ольгин. - На этот раз опять же таки хороша была г-жа Ясновская в роли наймички Стехи» [2. 1903. № 10. 14 янв. С. 3].

Более критические суждения об успехах украинской труппы содержатся в рецензии Всеволода Долгорукова от 16 января, который отмечает, что, к сожалению, часть томской публики не может отличить «посредственную оперетку» от «очень хорошей и идейной пьесы», каковой, по его мнению, является драма «Родина» Зудермана бенефисный спектакль артиста Быстрова. Известный томский литератор и критик отстаивает высокое искусство и стремится воспитать требовательного зрителя, который приходит в театр не только развлекаться, но и переживать, сострадать, испытывать катарсис [2. 1903. № 12. 16 янв. С. 3].

Суждения И. Ольгина о спектаклях и опереттах украинской труппы по-прежнему достаточно комплиментарны. В своей рецензии, помещенной в этом же номере «Сибирского вестника», он дает достаточно высокую оценку спектаклю по драме Л.Я. Манько «Нещасне кохання» («Несчастная любовь») $)^{1}$. «Малороссийская труппа Ф.А. Хмары положительно завоевала симпатии нашей публики. В такие дни, как понедельник и вторник, спектакли их проходят почти при полных сборах». Анализируя постановку драмы Манько, И. Ольгин опять выделяет Е.П. Ясновскую, на этот раз в трудной драматической роли Зарьки, отмечая, что «в четвертом и пятом актах игра ее доходила до совершенства, и г-жа Ясновская создала лицо, переживающее страшные нравственные потрясения» [Там же]. В очередной раз он хвалит хор и особенно выделяет исполнение квартетом песни на слова Т.Г. Шевченко «Реве та стогне Дніпр широ-

1 Леонид Яковлевич Манько (1863-1922) - украинский актёр, член труппы М.Л. Кропивницкого, известный исполнитель роли Гордея Поваренко в спектакле по пьесе Кропивницкого «Пока солнце взойдёт - роса очи выест». Автор пьес «Несчастная любовь», «Божья кара». 
кий». Заключает свою рецензию автор предположением, что труппа Хмары «вполне пришлась по вкусу томичам и будет подвизаться у нас не без успеха».

Во второй половине января произошло объединение двух трупп - украинской труппы Ф.А. Хмары и русской труппы Ю.Ф. Строговой. Украинская труппа получила возможность ставить свои спектакли на более престижной сцене - в театре Королёва, а русская труппа, не удовлетворенная кассовыми сборами, стремилась поправить свои дела за счет успеха своего партнера. Новый театральный коллектив получает название «Русско-малороссийская опереточно-драматическая труппа», главным руководителем его становится Ф.А. Хмара. На первой странице «Сибирского вестника» появляется анонс спектаклей объединенной труппы, которые теперь неизменно идут на сцене театра Королёва.

Состав украинской труппы за короткое время репетирует и ставит на сцене театра Королёва еще плохо освоенную русской сценой оперетту С. Джонса «Гейша, или Необычайное происшествие в одной японской чайной» (либретто О. Холла и Г. Гринбэнка). Неизвестная томской публике оперетта с интригующим названием вызвала необычайный интерес, и театр был переполнен. Вполне положительную оценку постановке оперетты дает Всеволод Долгоруков: «Исполнение оперетки я не могу назвать блестящим, но оно было именно вполне удовлетворительным. Хорошие свежие костюмы, хорошая декорация, недурные стройные хоры и изящная симпатичная Молли в лице г-жи Ясновской. У г-жи Ясновской недурной голос, как раз для оперетки, изящные, не без грации, манеры и некоторый опереточный шик. Особенно удались ей сцены во втором действии. Исполнение здесь вызвало шумные аплодисменты и требование повторений» [2. 1903. № 16. 21 янв. С. 3]. На этот раз рецензент отмечает также и игру исполнителей второстепенных ролей: Хмары в роли маркиза Имари и Зозули в роли китайца, содержателя чайного домика.

Повторное исполнение «Гейши» оказалось менее удачным, что отмечает в своей небольшой рецензии И. Ольгин, критикуя кордебалет и массовые сцены, в которых участвуют гейши, не умеющие обходиться с веером [2. 1903. № 18. 23 янв. С. 3]. Не совсем удачным в это время была также постановка Ю.Ф. Строговой пьесы М. Горького «Мещане». Но украинский состав объединенной труп- 
пы неизменно радовал томского зрителя, хотя на спектакле по драме Мирославского «Мазепа» 1 публики было не так много, но, как замечает Всеволод Долгоруков, «...оно и понятно; каждый день то спектакль, то концерт, и часто по два в один день, т.е. в двух, а иногда в трех местах - в театре, клубе и бесплатной библиотеке. Как хотите, но в Томске не сто тысяч жителей, и посетителей не может хватить на все развлечения» [2. 1903. № 20. 25 янв. С. 3]. Вместе с тем Неизменный театрал вновь выделил игру Ясновской, которая «с большим чувством и одушевлением провела роль дочери Кочубея - Марии». Резюмируя свои суждения о спектакле, критик заметил: «У малороссов, право, очень недурная труппа, есть две-три талантливые силы и главное очень недурное хорошее пение» [Там же].

В конце января отзывы об украинской труппе становятся более скупыми и сдержанными. Оно и понятно, новизна утрачена, многое в репертуаре повторяется. Поэтому об оперетте по повести Гоголя «Вий» рецензент И. Ольгин дает лишь краткую информацию: «В пятницу малороссы в театре во второй раз поставили оперетку «Вий». «Декоративно пьеса была обставлена прекрасно.<..> Все вокальные номера вызвали одобрение публики» [2. 1903. № 21. 26 янв. С. 3].

Нередко в один день объединенная труппа, чтобы привлечь зрителя, одновременно дает два представления, как это происходило, например, 23 января 1903 г., когда на сцене театра Королёва был поставлен бенефисный спектакль в честь В.П. Аркунина по «Отцам и детям» Тургенева и оперетта «малороссов» «Цыганские песни в лицах». Всеволод Долгоруков в своей краткой рецензии говорит о не совсем удачной переделке романа Тургенева, невысоком уровне исполнительского мастерства актеров, все же отмечая игру госпожи Абаровой в роли Одинцовой. Но свою оперетку украинцы, по словам Долгорукова, исполнили бойко и лихо [Там же].

В своей следующей рецензии от 2 февраля театральный критик отмечает целесообразность объединения двух трупп, что сказалось на посещаемости томской публикой театра Королёва: «Очевидно, что театр стал посещаться охотнее с того времени, когда антреприза пригла-

${ }^{1}$ Установить точные сведения об авторе драмы не удалось. Видимо, она представляла собой свободную переделку поэмы А.С. Пушкина «Полтава» либо драмы О. Шатковского «Мазепа» (1898). 
сила малороссийскую труппу и соединила обе труппы вместе» [2. 1903. № 27. 2 февр. С. 3]. В этой же рецензии он дает небольшой обзор спектаклю украинской труппы «Лиса Партикеевна», приуроченный к бенефису Е.П. Ясновской, которая не без успеха исполнила главную роль: «Г-жа Ясновская, несомненно, хорошая артистка, при том и внешность у нее миловидная и подкупающая» (Там же).

Следующие рецензии о спектаклях русского и украинского состава объединенной труппы очень сдержанны. Это относится к отзыву Долгорукова о драме по роману Г. Сенкевича «Камо грядеши» и Ольгина об оперетте «И ночь, и луна, и любовь» [2. 1903. № 28. 4 февр. С. 3 ; № 33.9 февр. С. 3 ].

Перед наступлением Великого поста проходят заключительные спектакли объединенной труппы, часто устраиваются бенефисы в честь ведущих актеров. Об одних бенефисах рецензенты дают лишь скупую информацию, как, например, о бенефисе В.Я. Шмардина в «Фоме Гордееве» Горького. В своей краткой заметке И. Ольгин отмечает «плохое исполнение пьесы», размышляя, что «не присутствующие зрители ничего не потеряли» [2. 1903. № 36.13 февр. С. 3].

Но о бенефисе С.М. Антонович при участии украинского состава труппы в опере С. Монюшко «Галька» Долгоруков не отделался скупыми замечаниями. Видимо, опера вызвала у томской публики неподдельный интерес, и ее постановка требовала профессионального истолкования. В своей рецензии Долгоруков вначале ограничивается общими сведениями, а затем касается качества игры актеров: «Исполнение было удовлетворительное и как в декоративном отношении, так и со стороны костюмов, довольно чистых, опера была обставлена недурно. Правда, у исполнявшего партию Антона г. Чернова очень слабый голос, не выдается голосовыми средствами и бенефициантка; тем не менее их пение было прочувствованно и игра не лишена была драматизма. Особенно г-жа Антонович правдиво исполнила сцены сумасшествия Гальки» [2. 1903. № 34. 11 февр. C. 3].

16 февраля на томской сцене были представлены прощальные спектакли: утром давалась «Гейша», а вечером «Запорожец за Дунаем» (вместо запланированной оперы А. Верстовского «Аскольдова могила»). После отъезда театральных трупп Долгоруков написал обширную рецензию в «Сибирском вестнике», размышляя о завершенном зимнем театральном сезоне в Томске. Он в целом дал невы- 
сокую оценку русской труппе, сформированной Ю.Ф. Строговой: «Драматическая труппа русская, сформированная г-жой Строговой, была бедна и в качественном, и в количественном отношении. Особенно был беден женский персонал труппы с таким ничтожным женским персоналом. Надо только удивляться г-же Строговой, опытной и даровитой артистке, знающей хорошо условия жизни нашего города, что она решилась выступить с такой труппой. В труппе, впрочем, были и недурные силы и их приходится жалеть, потому что они одни в некомплектной труппе ничего не могли сделать...» [2. 1903. № 38. 18 февр. С. 3].

Более высокую оценку получила украинская труппа под руководством Ф.А. Хмары, хотя, как отмечает рецензент, и она не была особенно сильна своим составом. «За исключением г-жи Ясновской и г. Хмара и Зозуля - остальные артисты были заурядные посредственности; но там были недурной хор, и пение народных малороссийских песен доставляло хотя некоторое удовольствие». Украинцы, по его мнению, внесли «некоторое оживление, и спектакли с участием их посещались охотнее». Исполнение опер им удавалось значительно хуже, за исполнением лишь «Гейши», исполнение которой «с участием артистов малорусской труппы прошло более удовлетворительно» [Там же].

Оценивая общий уровень театральных постановок, рецензент пишет и о томской театральной публике. Бурная театральномузыкальная жизнь культурной провинции сформировала своего требовательного зрителя, и он ожидает подлинного искусства, профессиональной режиссуры и исполнителей. «Поверьте, - заключает Долгоруков, - дайте хорошую труппу драматическую, оперную или опереточную, и Томск всегда ее окупит, и антрепренер останется с барышом»...» [Там же].

Пик гастролей украинских трупп в Томске пришелся на годы, предшествующие Первой русской революции и времени чрезвычайной популярности украинской комедии и мелодрамы в России. В последующие годы количество гастролей постепенно снижается. К тому же в Томске при Украинском клубе появляется самодеятельный театр, который в определенной мере удовлетворяет спрос на национальный украинский репертуар. 


\section{Литература}

1. Сибирская газета. 1882-1888.

2. Сибирский вестник. 1885-1905.

\section{MULTICULTURAL THEATRICAL DISCOURSE OF TOMSK AT THE TURN OF THE 19TH AND 20TH CENTURIES (BASED ON UKRAINIAN TOURING TROUPES).}

Text. Book. Publishing, 2015, 1 (8), 73-85. DOI 10.17223/23062061/8/6

Domansky Valery A. Leningrad Regional Institute of Education Development (St. Petersburg, Russian Federation). E-mail: valerii_domanski@mail.ru

Keywords: Tomsk periodicals, theatrical discourse, Ukrainian troupe, theater critics.

Theater plays a special role in the general cultural and civic development of the Siberian intelligentsia due to its accessibility and effect on the feelings of the audience. In Siberia, local theater groups appear regularly but touring troupes from Russian centers, from Ukraine and even artists from Europe come frequently. Almost all the leading Siberian newspapers publish the detailed analysis of the theater, the actors' play, and later even the works of Russian, Ukrainian and foreign opera.

Mainly, Tomsk theater history consists of separate plots of single plays and theater tours. Ukrainian touring troupes were a special chapter in the theatrical life of Tomsk, the rich details of which are presented on the pages of Sibirskiy vestnik ("Siberian Messenger") in the period from 1885 to 1904 . During this period several Ukrainian troupes stayed at Tomsk, among them was the founder of the Ukrainian theater troupe, M.L. Kropyvnytsky.

The Ukrainian troupe tour led by F.A. Chmara presents an interesting episode in multicultural discourse. The performances were held in Tomsk in the winter of 1903 and their reviews were presented in the publications by of Vs. Dolgorukov, I. Olguin, G. Vyatkin. Theater reviewers analyzed almost the entire repertoire of the Ukrainian troupe; the acting was professionally evaluated too. The Ukrainian touring troupe, which later consolidated with the Russian drama troupe of Yu.F. Strogova, made a significant contribution to the revival of the Russian province cultural life.

The Ukrainian touring troupe peak in Tomsk was in the years preceding the First Russian Revolution and the time of resettlement of Ukrainians in Siberia. Subsequently, the number of tours reduced gradually, which was due to the historical events and the creation of an amateur theater at the Ukrainian club which largely satisfied the audience demand for the Ukrainian national repertoire.

\section{References}

1. Sibirskaya gazeta, 1882-1888.

2. Sibirskiy vestnik, 1885-1905. 